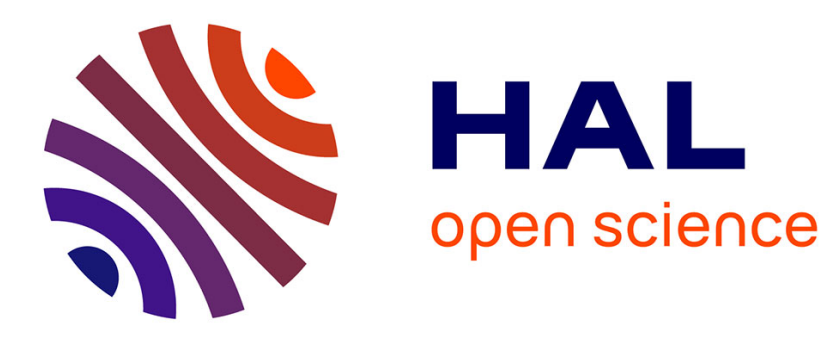

\title{
Insertion of a thin highly doped crystalline layer in silicon heterojunction solar cells: Simulation and perspectives towards a highly efficient cell concept
}

T. Carrere, R. Varache, D. Muñoz, Jean-Paul Kleider

\section{- To cite this version:}

T. Carrere, R. Varache, D. Muñoz, Jean-Paul Kleider. Insertion of a thin highly doped crystalline layer in silicon heterojunction solar cells: Simulation and perspectives towards a highly efficient cell concept. Journal of Renewable and Sustainable Energy, 2015, 7 (1), pp.011202. 10.1063/1.4908189 . hal-01231778

HAL Id: hal-01231778

https://hal-centralesupelec.archives-ouvertes.fr/hal-01231778

Submitted on 11 Mar 2020

HAL is a multi-disciplinary open access archive for the deposit and dissemination of scientific research documents, whether they are published or not. The documents may come from teaching and research institutions in France or abroad, or from public or private research centers.
L'archive ouverte pluridisciplinaire $\mathbf{H A L}$, est destinée au dépôt et à la diffusion de documents scientifiques de niveau recherche, publiés ou non, émanant des établissements d'enseignement et de recherche français ou étrangers, des laboratoires publics ou privés. 


\section{A Journal of Renewable and Sustainable Energy}

Insertion of a thin highly doped crystalline layer in silicon heterojunction solar cells: Simulation and perspectives towards a highly efficient cell concept

T. Carrere, R. Varache, D. Muñoz, and J. P. Kleider

Citation: Journal of Renewable and Sustainable Energy 7, 011202 (2015); doi: 10.1063/1.4908189

View online: http://dx.doi.org/10.1063/1.4908189

View Table of Contents: http://scitation.aip.org/content/aip/journal/jrse/7/1?ver=pdfcov

Published by the AIP Publishing

\section{Articles you may be interested in}

High efficiency solar cells combining a perovskite and a silicon heterojunction solar cells via an optical splitting system

Appl. Phys. Lett. 106, 013506 (2015); 10.1063/1.4905177

Amorphous silicon oxide window layers for high-efficiency silicon heterojunction solar cells

J. Appl. Phys. 115, 024502 (2014); 10.1063/1.4861404

High-efficiency heterojunction solar cells on crystalline germanium substrates

Appl. Phys. Lett. 101, 032102 (2012); 10.1063/1.4737166

Carrier transport and sensitivity issues in heterojunction with intrinsic thin layer solar cells on $\mathrm{N}$-type crystalline silicon: A computer simulation study

J. Appl. Phys. 107, 054521 (2010); 10.1063/1.3326945

Role of the buffer layer in the active junction in amorphous-crystalline silicon heterojunction solar cells

J. Appl. Phys. 88, 293 (2000); 10.1063/1.373656

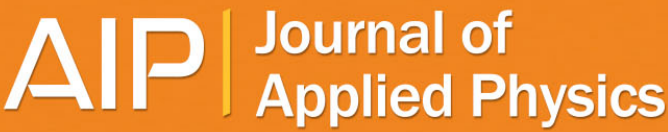

Journal of Applied Physics is pleased to

announce André Anders as its new Editor-in-Chief 


\title{
Insertion of a thin highly doped crystalline layer in silicon heterojunction solar cells: Simulation and perspectives towards a highly efficient cell concept
}

\author{
T. Carrere, ${ }^{1,2,3}$ R. Varache, ${ }^{1}$ D. Muñoz, ${ }^{1}$ and J. P. Kleider ${ }^{2}$ \\ ${ }^{1}$ CEA-INES, LITEN, Laboratoire HET, F-73375, 50 Avenue du Lac Léman, \\ Le Bourget-du-Lac, France \\ ${ }^{2}$ LGEP, UMR8507, F-91192, 11 rue Joliot Curie, Gif-sur-Yvette, France \\ ${ }^{3}$ French Environment and Energy Management Agency, 20 avenue du Grésillé BP 90406, \\ 49004 Angers Cedex 01, France
}

(Received 31 October 2014; accepted 23 January 2015; published online 10 February 2015)

\begin{abstract}
An emerging cell concept based on silicon heterojunctions called hetero-homojunction is investigated by means of numerical simulations. Compared to the usual amorphous/ crystalline silicon (a-Si:H/c-Si) heterojunction architecture, the heterohomojunction cell contains an additional thin and highly doped $\left(\mathrm{p}^{+}\right)-$or $\left(\mathrm{n}^{+}\right)-\mathrm{c}-\mathrm{Si}$ layer at the front or back (i)a-Si:H/(n)c-Si interface, respectively. In this paper, we show the dependence of solar cell performance on the additional heavily doped c-Si layer parameters (thickness and doping) and a-Si:H/c-Si interface properties. Insertion of the $\left(\mathrm{p}^{+}\right) \mathrm{c}-\mathrm{Si}$ improves the cell power conversion efficiency by almost $1 \%$ absolute and lowers its sensitivity to a-Si:H/c-Si interface defects. Improved field effect passivation leading to higher open circuit voltage and fill factor is evidenced and the added layer is optimized with regard to hetero-homojunction cell efficiency. The $\left(\mathrm{n}^{+}\right) \mathrm{c}$-Si layer addition also decreases the recombination rate at the back hetero-interface but does not improve significantly the conversion efficiency. The latter result is finally discussed. C 2015 AIP Publishing LLC.
\end{abstract}

[http://dx.doi.org/10.1063/1.4908189]

\section{INTRODUCTION}

Amorphous/crystalline silicon heterojunction (HET) (a-Si:H/c-Si) solar cell is a very promising technology to achieve high conversion efficiency at low manufacturing cost. ${ }^{1}$ The use of thin hydrogenated amorphous silicon $(\mathrm{a}-\mathrm{Si}: \mathrm{H})$ as an emitter has allowed several research institutes and companies to reach open circuit voltage $\left(\mathrm{V}_{\mathrm{OC}}\right)$ values above $720 \mathrm{mV}$ (Refs. 2-5) while $24.7 \%$ power conversion efficiency was recently demonstrated on industrial size wafers ${ }^{2}$ (25.6\% for rear contact HET cell $\left.{ }^{6}\right)$.

In today's HET cells, emitter passivation was identified as one of the most important issues. $^{7,8}$ Therefore, ways to further improve the quality of interfaces in the (p)a-Si:H/(i)a-Si:H/ (n)c-Si stack should be investigated to enhance cells' performance. On the one hand, the density of interface recombination centers $\left(\mathrm{D}_{\mathrm{it}}\right)$ can be reduced by surface cleaning or by improving the (i)a-Si:H passivation layer. ${ }^{8}$ On the other hand, a higher selectivity of the hetero-interface, i.e., the presence of only one type of charge carrier, decreases interface recombination ${ }^{9}$ leading to more efficient devices. The latter route, commonly called field effect passivation, could be realized through the addition of a thin and highly doped $\left(\mathrm{p}^{+}\right) \mathrm{c}-\mathrm{Si}$ layer underneath the (i)a-Si:H passivation layer. ${ }^{10}$ Because of the added $\left(\mathrm{p}^{+}\right) \mathrm{c}-\mathrm{Si} /(\mathrm{n}) \mathrm{c}-\mathrm{Si}$ homojunction, the alternative cell architecture can be referred to as a front side hetero-homojunction $\left(\mathrm{HHJ}_{\mathrm{FS}}\right)$. The $\mathrm{HHJ}_{\mathrm{FS}}$ architecture is introduced in Figure 1.

So far, only a few studies have investigated the hetero-homojunction concept. ${ }^{10-12}$ Zhong et al. simulated the previously defined $\mathrm{HHJ}_{\mathrm{FS}}$ cell but removed the (i)a-Si:H passivation layer. ${ }^{11}$ The cell displays $\mathrm{V}_{\mathrm{OC}}$ and fill factor $(\mathrm{FF})$ improvement and a reduced interface defect $\left(\mathrm{D}_{\mathrm{it}}\right)$ sensitivity (i.e., less performance reduction for increasing $\mathrm{D}_{\mathrm{it}}$ ). Field effect at the front interface 


\section{HET}
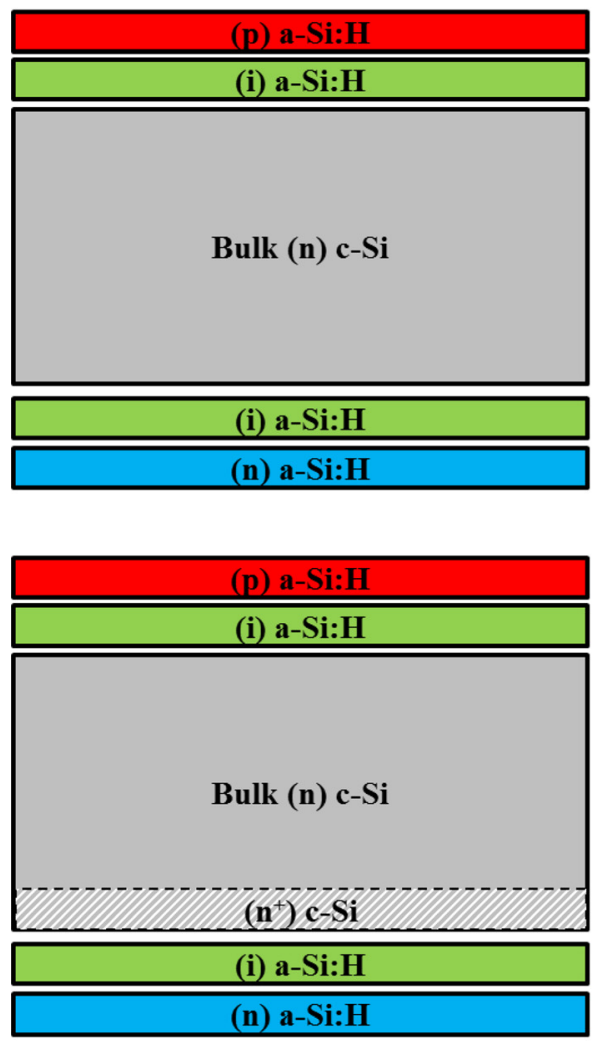

$\mathbf{H H J}_{\mathbf{B S}}$

\section{$\mathbf{H H J}_{\mathrm{FS}}$}
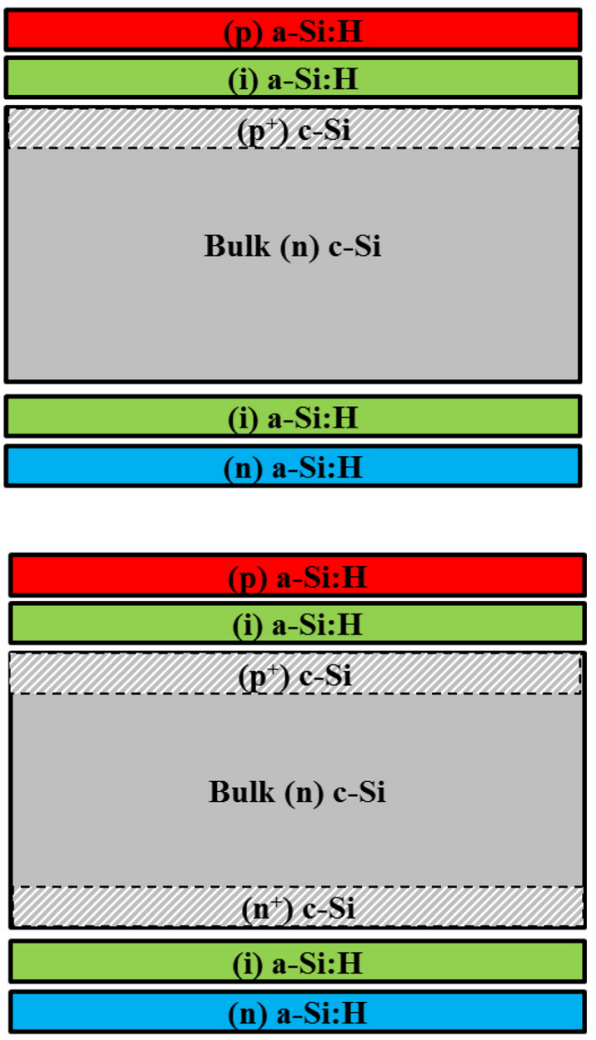

$\mathbf{H H J}_{\mathbf{F S}+\mathrm{BS}}$

FIG. 1. Scheme of the HET cell and of the various HHJ cell architectures with the inserted $\left(\mathrm{p}^{+}\right) \mathrm{c}-\mathrm{Si}$ or/and $\left(\mathrm{n}^{+}\right) \mathrm{c}-\mathrm{Si}$ layers.

was evidenced as the passivation improvement mechanism. However, Zhong's calculations were performed with the same interface defect density as in the "traditional" (p)a-Si:H/(i)a$\mathrm{Si}: \mathrm{H} /(\mathrm{n}) \mathrm{c}-\mathrm{Si}$ although the (i)a-Si:H passivation layer was removed, which is not realistic. In an experimental cell, the additional field effect brought by the $\left(\mathrm{p}^{+}\right) \mathrm{c}-\mathrm{Si}$ layer introduction may not be sufficient to compensate the loss of chemical passivation due to the (i)a-Si:H layer removal. In this case, all beneficial effects of the $\left(\mathrm{p}^{+}\right) \mathrm{c}-\mathrm{Si}$ layer would be lost.

Mikolášek et al. have simulated the $\mathrm{HHJ}_{\mathrm{FS}}$ architecture but on a p-type substrate (with an $\left(\mathrm{n}^{+}\right) \mathrm{c}$-Si layer addition) and using a rear contact cell. ${ }^{10}$ They added the homojunction, while conserving the (i)a-Si:H passivation layer. With such cell architecture, they observed a $\mathrm{V}_{\mathrm{OC}}$ improvement and a reduced interface defect sensitivity.

Hekmatshoar et al. manufactured a p-type $\mathrm{HHJ}_{\mathrm{FS}}$ cell but without the (i)a-Si:H passivation layer. ${ }^{12}$ However, the observed efficiency increase by $0.7 \%$ absolute (abs) (compared to the HET cell) cannot be directly attributed to front interface passivation improvement since the back side layer stack was also modified.

None of these studies focused on the role of the addition of the $\left(\mathrm{p}^{+}\right) \mathrm{c}-\mathrm{Si}$ layer alone, without removing the (i)a-Si:H passivation layer (required to achieve high chemical passivation, i.e., low $\mathrm{D}_{\mathrm{it}}$ ), on a n-type cell (which is nowadays used in industrial high-performance devices) and with a standard contact configuration.

This work aims at investigating the behavior of the hetero-homojunction cells as close as possible to experimentally achievable cells and comparing them to a state-of-the art HET cell. Thus, as described in Figure 1, we started from a standard n-type HET architecture to build the $\mathrm{HHJ}_{\mathrm{FS}}$ cell by inserting the $\left(\mathrm{p}^{+}\right) \mathrm{c}-\mathrm{Si}$ layer. The (i)a-Si:H passivation layer was kept so that any 
change can be attributed to the $\left(\mathrm{p}^{+}\right) \mathrm{c}-\mathrm{Si}$ layer insertion. Simulated cells are first described in Sec. II. They consist in a HET reference cell and in HHJ cells. In addition to the previously described $\mathrm{HHJ}_{\mathrm{FS}}$ architecture, a hetero-homojunction with an added $\left(\mathrm{n}^{+}\right) \mathrm{c}-\mathrm{Si}$ layer at the back interface $\left(\mathrm{HHJ}_{\mathrm{BS}}\right)$ and a heterojunction with both added $\left(\mathrm{p}^{+}\right)$- and $\left(\mathrm{n}^{+}\right)$-c-Si layer $\left(\mathrm{HHJ}_{\mathrm{FS}+\mathrm{BS}}\right)$ are also investigated. Cell parameters of the architectures are then compared in Sec. III. Finally, the cell performances are discussed in the light of recombination rates within the cells in Sec. IV. The $\mathrm{HHJ}_{\mathrm{FS}}$ cell behavior is investigated and the $\left(\mathrm{p}^{+}\right) \mathrm{c}-\mathrm{Si}$ layer is optimized by varying the layer doping level and thickness. The inserted $\left(\mathrm{n}^{+}\right) \mathrm{c}-\mathrm{Si}$ layer benefits in $\mathrm{HHJ}_{\mathrm{BS}}$ and $\mathrm{HHJ}_{\mathrm{FS}+\mathrm{BS}}$ cells are assessed and compared to the $\left(\mathrm{p}^{+}\right) \mathrm{c}-\mathrm{Si}$ layer insertion.

\section{SIMULATION MODELS}

Numerical simulations are performed using the 1D simulation software "Automat FOR Simulation of HETerostructure" (Afors-HET) developed at the Helmholtz Zentrum Berlin. ${ }^{13}$ Simulated cell architectures with the position of the added layers are presented in Figure 1.The corresponding band diagrams at equilibrium are presented in Figure 2.

Layer parameters are described in Table I. The HET cell layers ((i)a-Si:H excepted) are taken from Varache's work. ${ }^{17}$ The density of states (DOS) in the doped a-Si:H layers follows the defect pool model proposed by Powell and Deane. ${ }^{14-16}$ A simplified description of the DOS consisting in two deep Gaussian distributions was used in the (i)a-Si:H layers. No significant discrepancies could be found compared to the use of a DOS in (i)a-Si:H layers calculated according to the actual position of the Fermi energy $\left(\mathrm{E}_{\mathrm{F}}\right)$ within the bandgap that is close to that in the adjacent doped a-Si:H layer due to the band bending at the hetero-interface which causes a DOS re-equilibration. ${ }^{15}$

At front and back hetero-interfaces, defects are introduced using a $1 \mathrm{~nm}$-thick highly defective c-Si interfacial layer containing two Gaussian distributed density of states. ${ }^{17}$ The donorlike and the acceptor-like Gaussian distributions have their respective maximum at $0.56 \mathrm{eV}$ and $0.76 \mathrm{eV}$ above the valence band $\left(\mathrm{E}_{\mathrm{V}}\right)$. Both distributions have a standard deviation of $0.2 \mathrm{eV}$ and electron and holes capture cross sections $\left(\sigma_{\mathrm{e}}, \sigma_{\mathrm{h}}\right)$ of $3 \times 10^{-15} \mathrm{~cm}^{2}$. Their heights are adjusted to yield targeted equivalent interface defect densities (in $\mathrm{cm}^{-2}$ ).

In the high quality crystalline substrate (bulk $(\mathrm{n}) \mathrm{c}-\mathrm{Si}$ ), recombination centers are modelled with $10^{9} \mathrm{~cm}^{-3}$ neutral defects located at $0.56 \mathrm{eV}$ above $\mathrm{E}_{\mathrm{V} .}{ }^{17}$
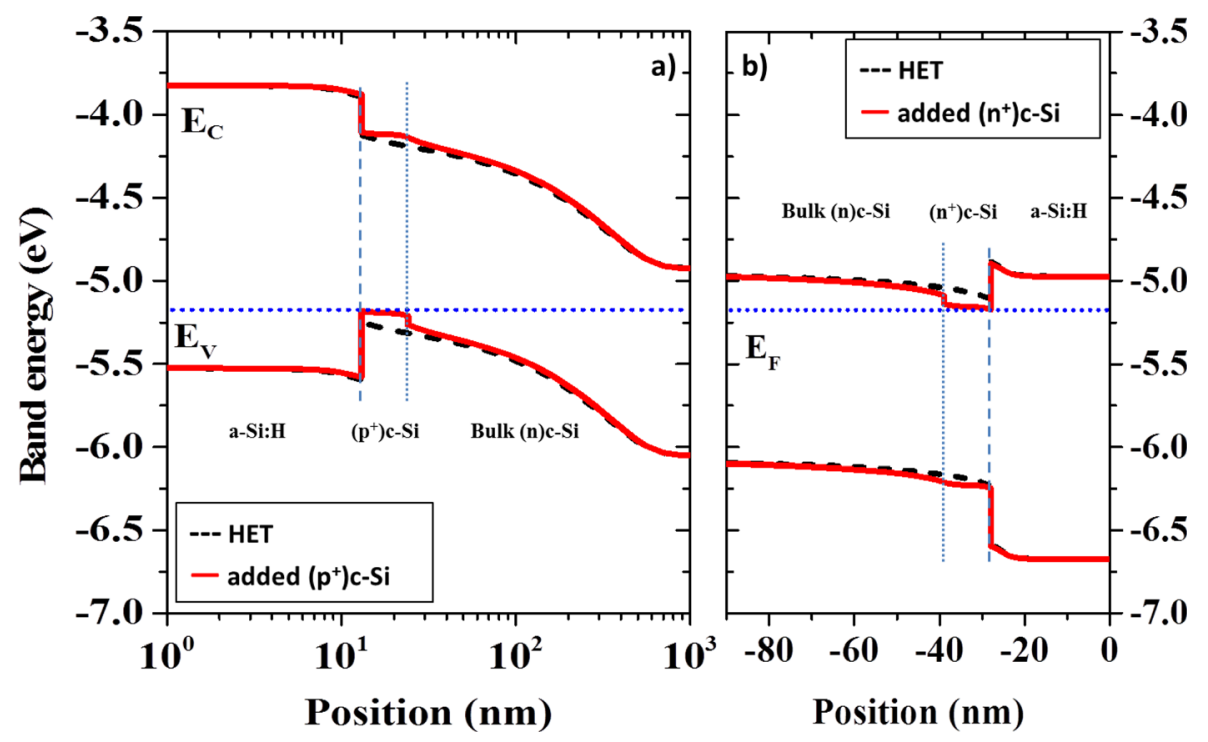

FIG. 2. Equilibrium band diagrams of the HET cell and the HHJ cells with the added layers at (a) the front interface and (b) at the back interface. 
TABLE I. Layer parameter.

\begin{tabular}{|c|c|c|c|c|c|c|c|}
\hline Layer parameters & Unit & (p)a-Si:H & (i)a-Si:H & (n)a-Si:H & Bulk (n)c-Si & Added $\left(\mathrm{p}^{+}\right) \mathrm{c}-\mathrm{Si}$ & Added $\left(\mathrm{n}^{+}\right) \mathrm{c}-\mathrm{Si}$ \\
\hline Thickness & $\ldots$ & $10 \mathrm{~nm}$ & $3 \mathrm{~nm}$ & $25 \mathrm{~nm}$ & $150 \mu \mathrm{m}$ & $0-1000 \mathrm{~nm}$ & $10 \mathrm{~nm}$ \\
\hline Optical and mobility gap & $\mathrm{eV}$ & 1.7 & 1.7 & 1.7 & 1.124 & $1.074-1.124$ & 1.124 \\
\hline Doping & $\mathrm{cm}^{-3}$ & $6.1 \times 10^{19}$ & 0 & $1.7 \times 10^{19}$ & $2.0 \times 10^{15}$ & $1 \times 10^{17}-5 \times 10^{18}$ & $5 \times 10^{18}$ \\
\hline Relative dielectric constant & $\ldots$ & 11.9 & 11.9 & 11.9 & 11.9 & 11.9 & 11.9 \\
\hline Electronic affinity & $\mathrm{eV}$ & 3.8 & 3.8 & 3.8 & 4.05 & 4.05 & 4.05 \\
\hline Electron (hole) mobility & $\mathrm{cm}^{2} \mathrm{~V}^{-1} \mathrm{~s}^{-1}$ & $0.5(0.5)$ & $0.5(0.5)$ & $0.5(0.5)$ & $1321(461)$ & $225-1321(96-461)$ & $151.9(164)$ \\
\hline $\begin{array}{l}\text { Total state density in } \mathrm{CB} \\
\text { (VB) }\end{array}$ & $\mathrm{cm}^{-3}$ & $\begin{array}{l}6.90 \times 10^{20} \\
\left(1.20 \times 10^{21}\right)\end{array}$ & $\begin{array}{l}6.90 \times 10^{20} \\
\left(1.20 \times 10^{21}\right)\end{array}$ & $\begin{array}{l}6.90 \times 10^{20} \\
\left(1.20 \times 10^{21}\right)\end{array}$ & $\begin{array}{l}2.8 \times 10^{19} \\
\left(2.7 \times 10^{19}\right)\end{array}$ & $1.1 \times 10^{19}\left(1.0 \times 10^{19}\right)$ & $\begin{array}{l}1.1 \times 10^{19} \\
\left(1.0 \times 10^{19}\right)\end{array}$ \\
\hline $\begin{array}{l}\text { Neutral defect (at } 0.56 \mathrm{eV}) \\
\text { concentration }\end{array}$ & $\mathrm{cm}^{-3}$ & $\ldots$ & $\ldots$ & $\ldots$ & $10^{9}$ & $10^{14}$ & $10^{14}$ \\
\hline $\begin{array}{l}\text { CB tail (VB tail) Urbach } \\
\text { energy }\end{array}$ & $\mathrm{eV}$ & $0.034(0.060)$ & $0.035(0.050)$ & $0.023(0.060)$ & $\ldots$ & $\ldots$ & $\ldots$ \\
\hline$\sigma_{\mathrm{e}}$ and $\sigma_{\mathrm{h}}$ for $\mathrm{CB}$ tail & $\mathrm{cm}^{2}$ & $7 \times 10^{-16}$ & $7 \times 10^{-16}$ & $7 \times 10^{-16}$ & $\ldots$ & $\ldots$ & $\ldots$ \\
\hline$\sigma_{\mathrm{e}}$ and $\sigma_{\mathrm{h}}$ for VB tail & $\mathrm{cm}^{2}$ & $7 \times 10^{-16}$ & $7 \times 10^{-16}$ & $7 \times 10^{-16}$ & $\ldots$ & $\ldots$ & $\ldots$ \\
\hline $\begin{array}{l}\text { Maximum A- and D-like } \\
\text { Gaussian state density }\end{array}$ & $\mathrm{cm}^{-3} \mathrm{eV}^{-1}$ & $1.20 \times 10^{20}$ & $1.00 \times 10^{17}$ & $2.25 \times 10^{19}$ & $\ldots$ & $\ldots$ & $\ldots$ \\
\hline $\begin{array}{l}\text { Position of the A-(D-)like } \\
\text { Gaussian (from valence band } \\
\text { edge) }\end{array}$ & $\mathrm{eV}$ & $1.450(1.250)$ & $1.025(0.725)$ & $0.850(0.650)$ & $\ldots$ & $\ldots$ & $\ldots$ \\
\hline $\begin{array}{l}\text { Standard deviation of the A- } \\
\text { and D-like Gaussian }\end{array}$ & $\mathrm{eV}$ & 0.19 & 0.10 & 0.19 & $\ldots$ & $\ldots$ & $\ldots$ \\
\hline $\begin{array}{l}\sigma_{\mathrm{e}}\left(\sigma_{\mathrm{h}}\right) \text { for A-like Gaussian } \\
\text { states }\end{array}$ & $\mathrm{cm}^{2}$ & $3 \times 10^{-15}\left(3 \times 10^{-14}\right)$ & $3 \times 10^{-15}\left(3 \times 10^{-14}\right)$ & $3 \times 10^{-15}\left(3 \times 10^{-14}\right)$ & $\ldots$ & $\ldots$ & $\ldots$ \\
\hline $\begin{array}{l}\sigma_{\mathrm{e}}\left(\sigma_{\mathrm{h}}\right) \text { for D-like Gaussian } \\
\text { states }\end{array}$ & $\mathrm{cm}^{2}$ & $3 \times 10^{-14}\left(3 \times 10^{-15}\right)$ & $3 \times 10^{-14}\left(3 \times 10^{-15}\right)$ & $3 \times 10^{-14}\left(3 \times 10^{-15}\right)$ & $\ldots$ & $\ldots$ & $\ldots$ \\
\hline
\end{tabular}


In the highly doped added layers, defects are also located at $0.56 \mathrm{eV}$ above $\mathrm{E}_{\mathrm{V}}$ but Shockley-Read-Hall (SRH) recombination dependence on doping is taken into account in the capture time constant: $\tau_{i 0}=\tau_{i 0 \_i n i} *\left(\frac{10^{15}}{N_{D}}\right)^{0.4}\left(\mathrm{i}=\mathrm{p}\right.$ or $\mathrm{n}$ ) and $\tau_{\mathrm{i} 0 \_ \text {ini }}$ set at $10^{-7} \mathrm{~s}$ using the SRH parameters (thermal velocity, defect density, and capture cross section). The lifetime values obtained with this model are below the ones that can be found in literature from other models. ${ }^{18,19}$ As a consequence the potential beneficial effects of the $\left(\mathrm{p}^{+}\right) \mathrm{c}$-Si layer insertion are not overestimated.

Regarding the carrier transport mechanism we considered drift-diffusion for homo-interfaces (c-Si/c-Si and a-Si:H/a-Si:H) and thermal emission with tunneling for hetero-interfaces (c-Si/a-Si:H). Bandgap narrowing due to the high doping level of the added crystalline layers is taken into account. Interface defect densities $\left(D_{i t}\right)$ and external resistances were tuned so that the simulated HET cell displays performances comparable to that of state-of-the art manufactured cells. $\mathrm{D}_{\text {it }}$ values are set at $5 \times 10^{9}$ and $1 \times 10^{9} \mathrm{~cm}^{-2}$ at the front and back hetero-interface, respectively. External resistances are set at 0.5 and $10^{5} \Omega \mathrm{cm}^{2}$ for series and parallel resistances, respectively.

\section{RESULTS}

Figure 3 presents the HET and $\mathrm{HHJ}_{\mathrm{FS}}$ cells' performance as a function of front interface defect density $\left(\mathrm{D}_{\mathrm{it}}\right)$. Since the front contact limits the cells passivation, simplified architectures without back side (i)a-Si:H layer and interfacial defects are used for computing time issues. In the simplified architectures, $\mathrm{D}_{\mathrm{it}}$ and series resistance are adjusted to $6 \times 10^{9} \mathrm{~cm}^{-2}$ and $0.3 \Omega$ $\mathrm{cm}^{2}$, respectively, in order to keep the HET cell parameters.

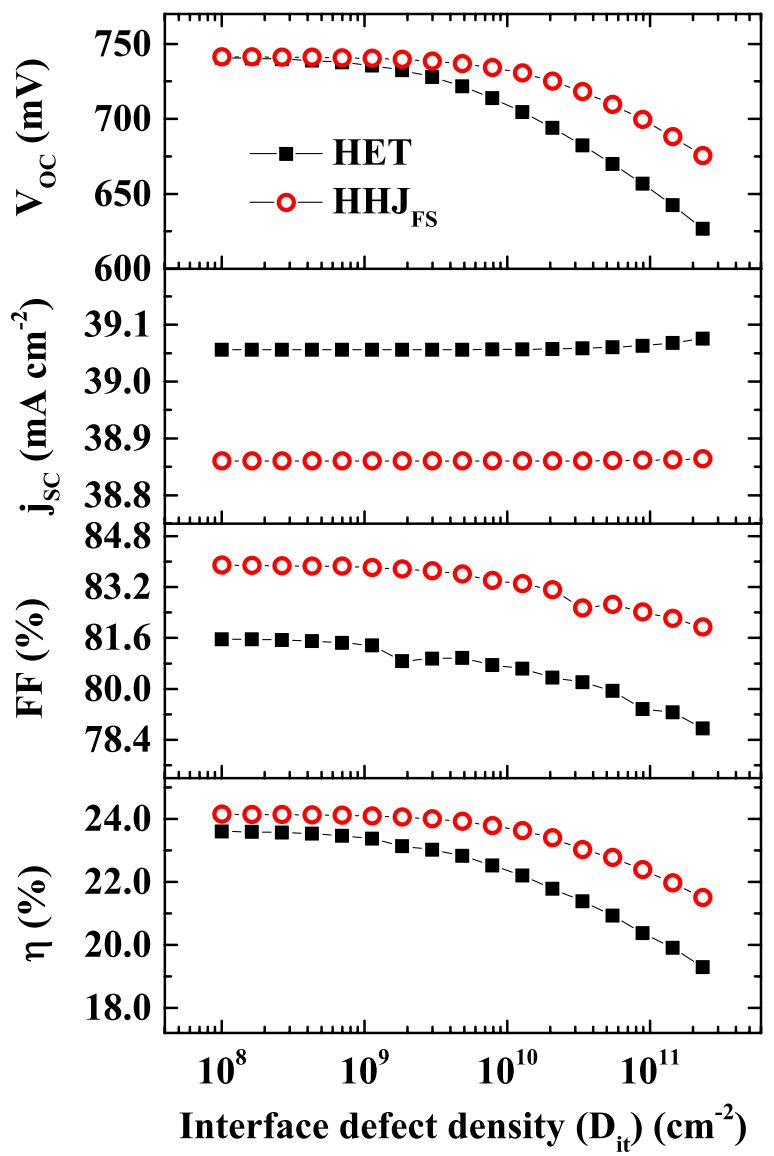

FIG. 3. Simplified HET $(\square)$ and $\mathrm{HHJ}_{\mathrm{FS}}$ (red circle) cells output parameters versus $\mathrm{D}_{\mathrm{it}}$. In the $\mathrm{HHJ}_{\mathrm{FS}}$ cell, the $\left(\mathrm{p}^{+}\right) \mathrm{c}-\mathrm{Si}$ doping level and layer thickness are set at $5 \times 10^{18} \mathrm{~cm}^{-3}$ and $10 \mathrm{~nm}$, respectively. 
In accordance with Zhong's results, $\mathrm{V}_{\mathrm{OC}}$ and $\mathrm{FF}$ improvements are observed with the addition of the $\left(\mathrm{p}^{+}\right) \mathrm{c}-\mathrm{Si}$ layer. Above $\mathrm{D}_{\mathrm{it}}=10^{9} \mathrm{~cm}^{-2}, \mathrm{~V}_{\mathrm{OC}}$ decreases more slowly with increasing $D_{i t}$ for the $H_{H J}$ architecture, and FF is also slightly less sensitive to $D_{i t}$ than in the HET cell. The reduced $D_{i t}$ sensitivity seems to strengthen for high $D_{i t}$. The short circuit current $\left(j_{S C}\right)$ is only very slightly lower in the $\mathrm{HHJ}_{\mathrm{FS}}$ cell. As a result, for any $\mathrm{D}_{\mathrm{it}}$, the $\mathrm{HHJ}_{\mathrm{FS}}$ cell has higher power conversion efficiency than the HET cell. When both cells have equal $\mathrm{V}_{\mathrm{OC}}$ (i.e., for low $\mathrm{D}_{\mathrm{it}}$ ), the $\mathrm{HHJ}_{\mathrm{FS}}$ efficiency is still improved by $0.5 \%$ absolute (abs) thanks to the FF improvement.

The $\mathrm{HHJ}_{\mathrm{FS}}$ concept is then extended by inserting a thin and highly doped $\left(\mathrm{n}^{+}\right) \mathrm{c}-\mathrm{Si}$ layer at the (i)a-Si:H/(n)c-Si back interface. Using the non-simplified architectures, the cell architectures $\left(\mathrm{HHJ}_{\mathrm{FS}}, \mathrm{HHJ}_{\mathrm{BS}}\right.$, and $\left.\mathrm{HHJ}_{\mathrm{FS}+\mathrm{BS}}\right)$ are compared in Table II. Both $\left(\mathrm{n}^{+}\right)-$and $\left(\mathrm{p}^{+}\right)$-c-Si layers have doping and thickness of $5 \times 10^{18} \mathrm{~cm}^{-3}$ and $10 \mathrm{~nm}$, respectively.

When adding a $\left(\mathrm{n}^{+}\right) \mathrm{c}$-Si layer at the back interface of the HET and $\mathrm{HHJ}_{\mathrm{FS}}$ cells (i.e., $\mathrm{HHJ}_{\mathrm{BS}}$ and $\mathrm{HHF}_{\mathrm{BS}+\mathrm{FS}}$, respectively), $\mathrm{V}_{\mathrm{OC}}$ and $\mathrm{FF}$ are only slightly improved and there is no $\mathrm{j}_{\mathrm{sC}}$ decrease. As a result, the cells efficiency gain is very low as compared to the HET and $\mathrm{HHJ}_{\mathrm{FS}}$ cells.

\section{DISCUSSION}

\section{A. Role of $\left(p^{+}\right) c-S i$ layer addition}

From the band diagram presented in Figure 2, an improved field effect is observed with the highly doped layers addition. Therefore, $\mathrm{V}_{\mathrm{OC}}$ and $\mathrm{FF}$ improvements brought by the $\left(\mathrm{p}^{+}\right) \mathrm{c}-\mathrm{Si}$ layer addition at the front interface are expected to originate from an enhanced field effect passivation of this critical interface. Figure 4 introduces the recombination rate as a function of the position in the cell, near the front interface, for both simplified $\mathrm{HET}$ and $\mathrm{HHJ}_{\mathrm{FS}}$ architectures in open-circuit conditions. In order to compare interface and bulk passivation, the recombination rate has been integrated over the layers thickness and expressed in $\mathrm{cm}^{-2} \mathrm{~s}^{-1}$ as shown in the inserted table in Figure 4.

Recombination at the HET cell front interface is much higher than in the c-Si region and thus limits the passivation. At this critical interface, the recombination rate is substantially lower for the $\mathrm{HHJ}_{\mathrm{FS}}$ cell. Therefore, $\mathrm{V}_{\mathrm{OC}}$ and $\mathrm{FF}$ improvements in $\mathrm{HHJ}_{\mathrm{FS}}$ are related to a lower recombination rate at the cell front interface. Since simulated $\mathrm{HET}$ and $\mathrm{HHJ}_{\mathrm{FS}}$ cells have equal $\mathrm{D}_{\mathrm{it}}$, the improvement brought by the $\left(\mathrm{p}^{+}\right) \mathrm{c}-\mathrm{Si}$ layer addition can be attributed to an enhanced field effect passivation. This is also confirmed by a lower electron concentration at the interface for the $\mathrm{HHJ}_{\mathrm{FS}}$ cell $\left(2 \times 10^{13} \mathrm{~cm}^{-3}\right)$ compared to the HET cell $\left(8 \times 10^{13} \mathrm{~cm}^{-3}\right)$. The observed recombination rate increase in the $\mathrm{HHF}_{\mathrm{FS}}$ substrate is another indicator of the cell passivation improvement. Indeed, since there is less recombination at the interface, the free carrier concentration increases in the cell. On the one hand, a higher free carrier concentration in the substrate is related to a higher $\mathrm{V}_{\mathrm{OC}}$. On the other hand, recombination mechanisms (e.g., Auger or SRH)

TABLE II. Non-simplified HET and HHJ cell architectures parameter. Front and back interface have $\mathrm{D}_{\mathrm{it}}$ equal to $5 \times 10^{9}$ and $1 \times 10^{9} \mathrm{~cm}^{-2}$, respectively.

\begin{tabular}{lcccc}
\hline \hline & $\mathrm{HET}$ & $\mathrm{HHJ}_{\mathrm{FS}}$ & $\mathrm{HHJ}_{\mathrm{BS}}$ & $\mathrm{HHJ}_{\mathrm{FS}+\mathrm{BS}}$ \\
\hline $\begin{array}{l}\text { Added layers } \\
\left(\mathrm{p}^{+}\right) \mathrm{c}-\mathrm{Si} \text { at front interface }\end{array}$ & & & $\mathrm{X}$ \\
$\left(\mathrm{n}^{+}\right) \mathrm{c}-\mathrm{Si}$ at back interface & & $\mathrm{X}$ & $\mathrm{X}$ \\
Cell parameters & & & \\
$\mathrm{V}_{\mathrm{OC}}(\mathrm{mV})$ & 713 & 730 & 716 & 737 \\
jSC $\left(\mathrm{mA} \mathrm{cm}{ }^{-2}\right)$ & 39.2 & 38.9 & 39.2 & 38.9 \\
FF $(\%)$ & 81.3 & 79.5 & 81.6 \\
$\eta(\%)$ & 79.3 & 23.1 & 22.3 & 23.4 \\
\hline \hline
\end{tabular}




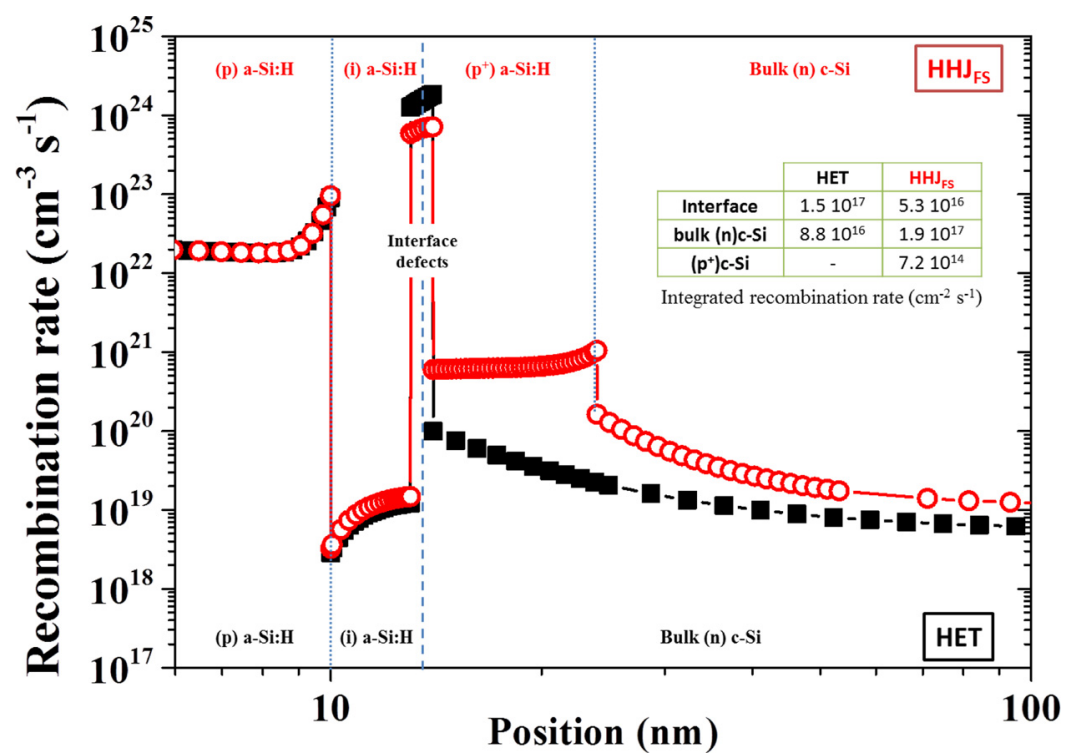

FIG. 4. Recombination rate in the simplified $\mathrm{HET}(\mathbf{\square})$ and $\mathrm{HHJ}_{\mathrm{FS}}$ (red circle) cells in $\mathrm{V}_{\mathrm{OC}}$ conditions. The inserted table displays the integrated recombination rate at the interface and in the crystalline regions. In $\mathrm{HHJ}_{\mathrm{FS}}$, the $\left(\mathrm{p}^{+}\right) \mathrm{c}-\mathrm{Si}$ layer doping density and thickness are set at $5 \times 10^{18} \mathrm{~cm}^{-3}$ and $10 \mathrm{~nm}$, respectively. For all structures $D_{\text {it }}$ is taken equal to $6 \times 10^{9}$ $\mathrm{cm}^{-2}$.

are enhanced in the substrate. Thus, the observed recombination increase in the substrate is not a drawback but slightly moderates the $\left(\mathrm{p}^{+}\right) \mathrm{c}-\mathrm{Si}$ layer benefits. However, due to its high doping level, the $\left(\mathrm{p}^{+}\right) \mathrm{c}-\mathrm{Si}$ layer is more defective and introduces strong additional recombination.

The $\mathrm{j}_{\mathrm{SC}}$ decrease with the $\left(\mathrm{p}^{+}\right) \mathrm{c}-\mathrm{Si}$ layer addition is later discussed in Sec. IV C.

In an experimental $\mathrm{HHJ}_{\mathrm{FS}}$ cell, the FF could be further enhanced by the $\left(\mathrm{p}^{+}\right) \mathrm{c}-\mathrm{Si}$ layer which promotes carrier lateral transport within the inversion layer. Indeed, due to the high band bending in crystalline silicon (see Figure 2(a)), the c-Si substrate type is inverted near the hetero-interface and the p-n junction is located in the crystalline wafer. ${ }^{20,21}$ The resulting inversion layer is very conductive compared to amorphous silicon layers and thus might promote lateral transport. ${ }^{22,23}$ As a consequence, improving the doping in this region by the $\left(\mathrm{p}^{+}\right) \mathrm{c}$-Si layer addition can enhance lateral transport in the inversion layer leading to even higher FF. This phenomenon cannot be directly observed in our simulations since Afors-HET is a 1D simulation model. However, from the simulated minority carrier density, the sheet resistance of the inversion layer was calculated. $\mathrm{HHJ}_{\mathrm{FS}}$ inversion layer sheet resistance $\left(7.1 \times 10^{3} \Omega / \square\right)$ is twice lower than the HET inversion layer $\left(1.5 \times 10^{4} \Omega / \square\right)$ but one order of magnitude higher than the Indium Tin Oxide (ITO) layer on top of the cell $\left(\sim 1 \times 10^{2} \Omega / \square\right)$. Therefore, it can be concluded that the $\left(\mathrm{p}^{+}\right) \mathrm{c}-\mathrm{Si}$ layer enhances the lateral transport in the inversion layer but should not contribute significantly to further FF improvement.

The reduced $\mathrm{D}_{\mathrm{it}}$ dependence of the $\mathrm{HHJ}_{\mathrm{FS}}$ architecture opens a new way to take advantage of the architecture: rather than enhancing the conversion efficiency, the $\mathrm{HHJ}_{\mathrm{FS}}$ cell could be a way for cost savings. For instance reducing interface cleaning steps duration (or passivation layers thickness) might decrease the manufacturing costs while keeping similar cell efficiency.

From Figure 4, we have seen that the $\left(\mathrm{p}^{+}\right) \mathrm{c}-\mathrm{Si}$ layer decreases recombination at the front interface but also that the layer is highly recombining. Though for a $10 \mathrm{~nm}$-thick $\left(\mathrm{p}^{+}\right) \mathrm{c}-\mathrm{Si}$ layer the added recombination within the layer $\left(7.2 \times 10^{14} \mathrm{~cm}^{-2} \mathrm{~s}^{-1}\right)$ is much lower than at the $\mathrm{HHJ}_{\mathrm{FS}}$ cell interface $\left(5.3 \times 10^{16} \mathrm{~cm}^{-2} \mathrm{~s}^{-1}\right)$, it is nevertheless a counterpart to the added layer benefits. Additionally, with increasing layer thickness, recombination in the $\left(\mathrm{p}^{+}\right) \mathrm{c}-\mathrm{Si}$ layer could also become predominant. Therefore, $\left(\mathrm{p}^{+}\right) \mathrm{c}-\mathrm{Si}$ parameters such as doping level and layer thickness should be optimized to maximize the added layer benefits. This is precisely the objective of Sec. IV B. 


\section{B. $\left(p^{+}\right) c-S i$ layer optimization}

In Figure 5, $\mathrm{V}_{\mathrm{OC}}$ and recombination rates at the front interface and within the $\left(\mathrm{p}^{+}\right) \mathrm{c}-\mathrm{Si}$ layer are plotted versus the layer doping level for simplified HET and $\mathrm{HHJ}_{\mathrm{FS}}$ cells in open circuit voltage conditions.

$\left(\mathrm{p}^{+}\right) \mathrm{c}-\mathrm{Si}$ doping higher than $5 \times 10^{18} \mathrm{~cm}^{-3}$ could not be considered. Indeed, for higher doping the Fermi energy enters into the valence band (below $E_{V}$ ). In this situation, the Fermi-Dirac statistic that is not implemented in the software should be considered instead of Boltzmann's statistics.

From Figure 5, it is seen that improving the $\left(\mathrm{p}^{+}\right) \mathrm{c}-\mathrm{Si}$ layer doping decreases recombination both at the interface and within the $\left(\mathrm{p}^{+}\right) \mathrm{c}-\mathrm{Si}$ layer. Therefore, field effect passivation is beneficial to repel electrons from both the interface and the recombining $\left(\mathrm{p}^{+}\right) \mathrm{c}-\mathrm{Si}$ layer. This explains the monotonous passivation increase with increasing the $\left(\mathrm{p}^{+}\right) \mathrm{c}-\mathrm{Si}$ doping. No $\mathrm{j}_{\mathrm{SC}}$ variation with doping was observed. Therefore, having a high $\left(\mathrm{p}^{+}\right) \mathrm{c}-\mathrm{Si}$ doping is beneficial for the cell passivation and performance.

However, because of the high recombination rate within the $\left(\mathrm{p}^{+}\right) \mathrm{c}-\mathrm{Si}$ layer, there is, for a given layer doping, an optimum layer thickness which maximizes the $\mathrm{HHJ}_{\mathrm{FS}}$ cell efficiency. Simplified $\mathrm{HHJ}_{\mathrm{FS}}$ cell output parameters are plotted versus the $\left(\mathrm{p}^{+}\right) \mathrm{c}-\mathrm{Si}$ layer thickness in Figure 6. In Table III, recombination rates within the cell are presented for 10, 100, and $1000 \mathrm{~nm}\left(\mathrm{p}^{+}\right) \mathrm{c}-\mathrm{Si}$ layer thickness.

For a $\left(\mathrm{p}^{+}\right) \mathrm{c}-\mathrm{Si}$ layer thickness of approximately $10 \mathrm{~nm}$, the $\mathrm{V}_{\mathrm{OC}}$ and $\mathrm{FF}$ of the $\mathrm{HHJ}_{\mathrm{FS}}$ cell rise up to their maximum. At this point, recombination at the interface has become lower than in the substrate (bulk $(\mathrm{n}) \mathrm{c}-\mathrm{Si}$ ) and recombination brought by the $\left(\mathrm{p}^{+}\right) \mathrm{c}-\mathrm{Si}$ layer addition is very low. Then, due to the recombination brought by the added layer, these parameters slowly decrease for an increasing $\left(\mathrm{p}^{+}\right) \mathrm{c}-\mathrm{Si}$ thickness. The decrease is slow because the passivation is now limited by recombination in the substrate.

$\mathrm{j}_{\mathrm{SC}}$ decreases very slowly with increasing the layer thickness. The sudden FF drop around $150 \mathrm{~nm}$ could not be physically explained. Therefore, it is supposed to originate from calculation issues. It has nevertheless a small influence on the cell efficiency.

From these observations, optimum thicknesses calculated for the tested $\left(\mathrm{p}^{+}\right) \mathrm{c}-\mathrm{Si}$ layer doping and the corresponding maximized $\mathrm{HHJ}_{\mathrm{FS}}$ cell efficiency are presented in Figure 7.

When increasing the doping density, the maximum achievable efficiency increases. This is in accordance with the passivation improvement previously observed both at the interface and within the $\left(\mathrm{p}^{+}\right) \mathrm{c}-\mathrm{Si}$ layer with increasing doping. However, the corresponding optimum thickness decreases for increasing doping. This results from stronger recombination within the $\left(\mathrm{p}^{+}\right) \mathrm{c}-\mathrm{Si}$ layer at high doping level.

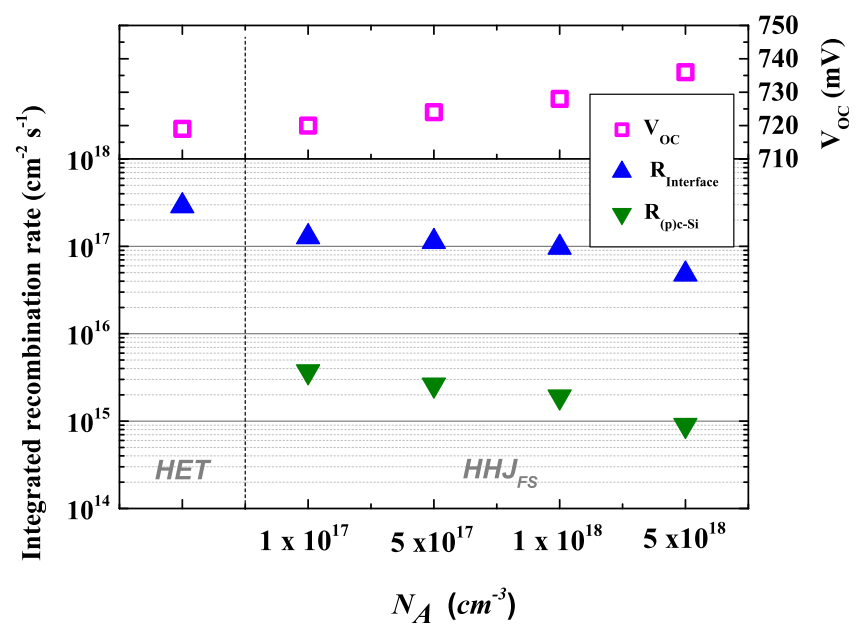

FIG. 5. $\mathrm{V}_{\mathrm{OC}}$ and integrated recombination rates (R) of simplified $\mathrm{HET}$ and $\mathrm{HHJ}_{\mathrm{FS}}$ cells at the interface and within the added $\left(\mathrm{p}^{+}\right) \mathrm{c}-\mathrm{Si}$ layer versus layer doping level. $\mathrm{In} \mathrm{HHJ}_{\mathrm{FS}}$, the $\left(\mathrm{p}^{+}\right) \mathrm{c}-\mathrm{Si}$ layer is $10 \mathrm{~nm}$ thick. 


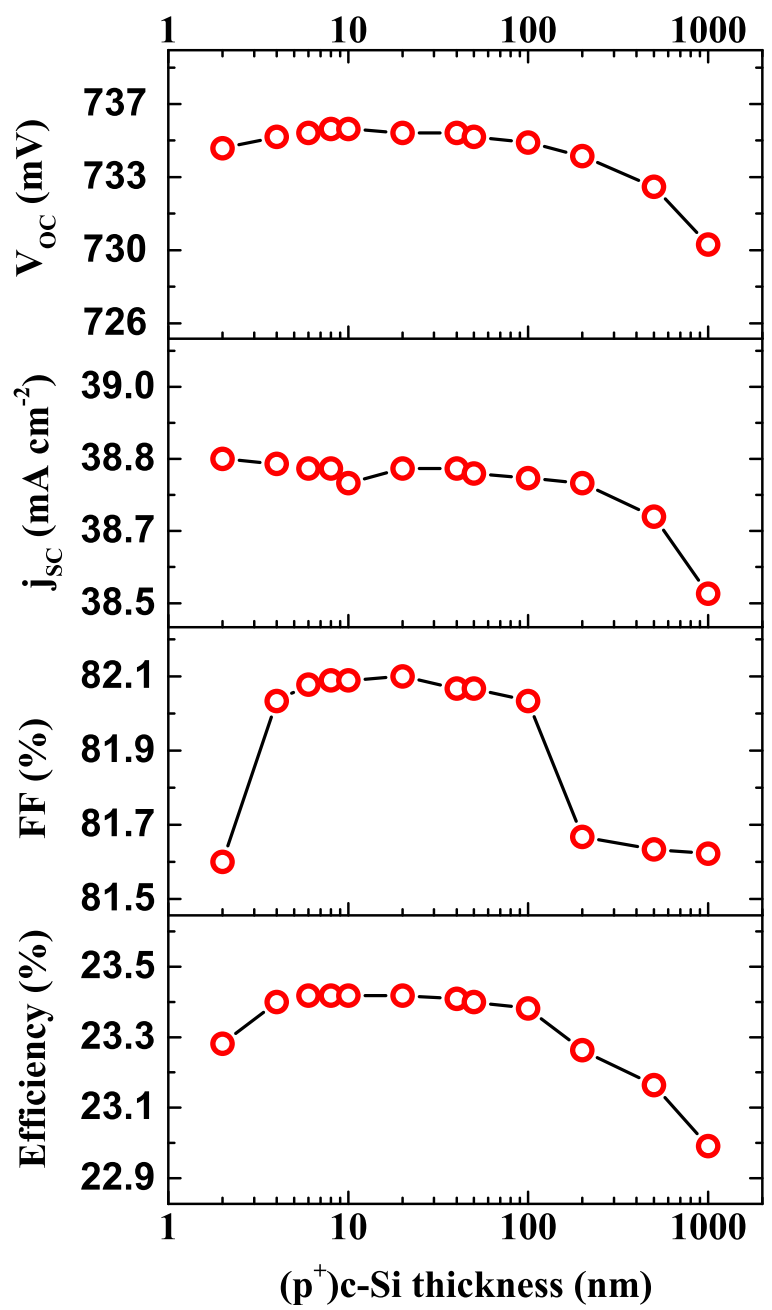

FIG. 6. Simplified $\mathrm{HHJ}_{\mathrm{FS}}$ cell output parameters versus $\left(\mathrm{p}^{+}\right) \mathrm{c}-\mathrm{Si}$ layer thickness. $\left(\mathrm{p}^{+}\right) \mathrm{c}-\mathrm{Si}$ layer doping is set at $5 \times$ $10^{18} \mathrm{~cm}^{-3}$.

From a practical point of view, such very thin optimized layers $(<40 \mathrm{~nm})$ would be difficult to experimentally achieve on large scale cells. However, from Figure 6, it is seen that the $\mathrm{HHJ}_{\mathrm{FS}}$ cell performance decreases only slightly for $\left(\mathrm{p}^{+}\right) \mathrm{c}-\mathrm{Si}$ layer thicknesses above its optimum. Therefore, under $100 \mathrm{~nm}$ thick, the $\left(\mathrm{p}^{+}\right) \mathrm{c}-\mathrm{Si}$ layer will retain most of the architecture advantages. Such layer thickness is nowadays achievable at relatively low cost thanks to alternative ion implantation and fast annealing processes. ${ }^{24,25}$ However, it should be noticed that the $\left(\mathrm{p}^{+}\right) \mathrm{c}-\mathrm{Si}$ layer created by ion implantation consists in a dopant depth profile rather than an homogeneous doping through the layer thickness, as simulated here. Thus, further work on dopant depth profile influence should be done.

TABLE III. $\mathrm{V}_{\mathrm{OC}}$ and integrated recombination rate $(\mathrm{R})$ at the interface, within the $\left(\mathrm{p}^{+}\right) \mathrm{c}-\mathrm{Si}$ layer, and in the substrate for the simplified $\mathrm{HHJ}_{\mathrm{FS}}$ cell with increasing $\left(\mathrm{p}^{+}\right) \mathrm{c}$-Si layer thickness. $\left(\mathrm{p}^{+}\right) \mathrm{c}-\mathrm{Si}$ layer doping is set at $5 \times 10^{18} \mathrm{~cm}^{-3}$.

\begin{tabular}{lcccc}
\hline \hline$\left(\mathrm{p}^{+}\right) \mathrm{c}-$ Si layer thickness $(\mathrm{nm})$ & $\mathrm{V}_{\text {OC }}(\mathrm{mV})$ & $\mathrm{R}_{\text {Interface }}\left(\mathrm{cm}^{-2} \mathrm{~s}^{-1}\right)$ & $\mathrm{R}_{(\mathrm{p}+) \mathrm{c}-\mathrm{Si}}\left(\mathrm{cm}^{-2} \mathrm{~s}^{-1}\right)$ & $\mathrm{R}_{\text {substrate }}\left(\mathrm{cm}^{-2} \mathrm{~s}^{-1}\right)$ \\
\hline 0 & 719 & $1.5 \times 10^{17}$ & $\ldots$ & $8.8 \times 10^{16}$ \\
10 & 736 & $5.3 \times 10^{16}$ & $7.2 \times 10^{14}$ & $1.9 \times 10^{17}$ \\
100 & 735 & $5.3 \times 10^{16}$ & $6.5 \times 10^{15}$ & $1.8 \times 10^{17}$ \\
1000 & 730 & $4.4 \times 10^{16}$ & $5.3 \times 10^{16}$ & $1.4 \times 10^{17}$ \\
\hline \hline
\end{tabular}




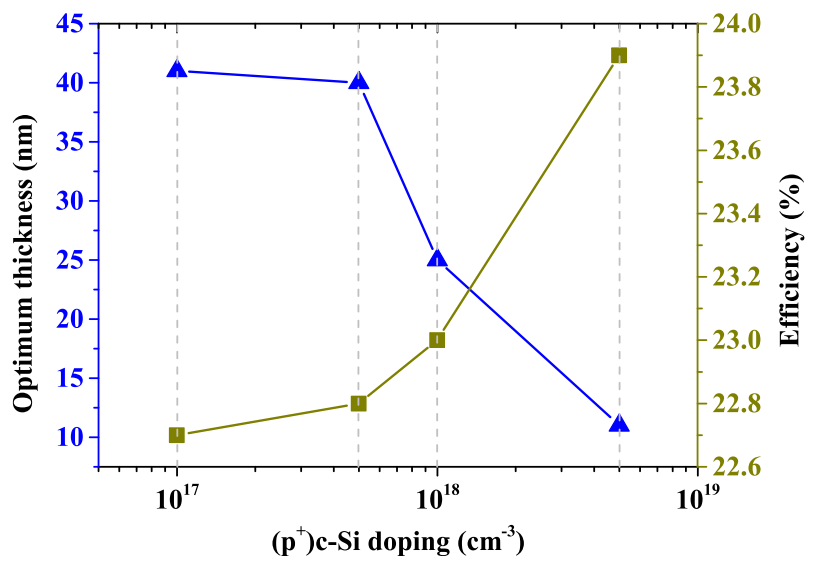

FIG. 7. $\left(\mathrm{p}^{+}\right) \mathrm{c}-\mathrm{Si}$ layer optimum thickness and related maximized $\mathrm{HHJ}_{\mathrm{FS}}$ cell efficiency as a function of the added layer doping.

The $\mathrm{HHJ}_{\mathrm{FS}}$ cell studied in Sec. IV A corresponds to an optimized cell for a doping density of $5 \times 10^{18} \mathrm{~cm}^{-3}$. As seen in the table of Figure 4, this cell is now limited by bulk recombinations since the bulk substrate has the highest integrated recombination rate. Therefore, substrate improvement is required to further enhance the $\mathrm{HHJ}_{\mathrm{FS}}$ structure.

\section{Addition of a $\left(\mathrm{n}^{+}\right) \mathrm{c}-\mathrm{Si}$ layer at the back (n)c-Si/(i)a-Si:H interface}

A main feature of the results presented in Table II is that the HHJ architectures only display significant passivation improvement (i.e., FF and $\mathrm{V}_{\mathrm{OC}}$ improvements) if they have the added $\left(\mathrm{p}^{+}\right) \mathrm{c}-\mathrm{Si}$ layer at the front interface $\left(\mathrm{HH}_{\mathrm{FS}}\right.$ and $\left.\mathrm{HH}_{\mathrm{FS}+\mathrm{BS}}\right)$. The addition of the $\left(\mathrm{n}^{+}\right) \mathrm{c}-\mathrm{Si}$ layer at the back interface does not improve significantly the cells performance. The recombination rates within the cell explain this behavior. Figure 8 presents integrated recombination rates at the front interface, back interface, and within the substrate (bulk (n)c-Si) and the corresponding $\mathrm{V}_{\mathrm{OC}}$ for $\mathrm{HET}$ and HHJ cells. As previously seen, recombination within the added doped layers can be neglected since the layers are very thin $(10 \mathrm{~nm})$.

The recombination rate at the HET cell front interface is one order of magnitude higher than at the back interface. Thus, the HET cell performance is limited by the front interface. The $\mathrm{HHJ}_{\mathrm{FS}}$ cell has its $\mathrm{V}_{\mathrm{OC}}$ limited by substrate recombination. Therefore, though the $\left(\mathrm{n}^{+}\right) \mathrm{c}-\mathrm{Si}$ layer addition in these cells decreases recombination at the back interface, the $\mathrm{HHJ}_{\mathrm{BS}}$ and $\mathrm{HHJ}_{\mathrm{FS}+\mathrm{BS}}$ cells display almost no performance enhancement as compared to the HET and

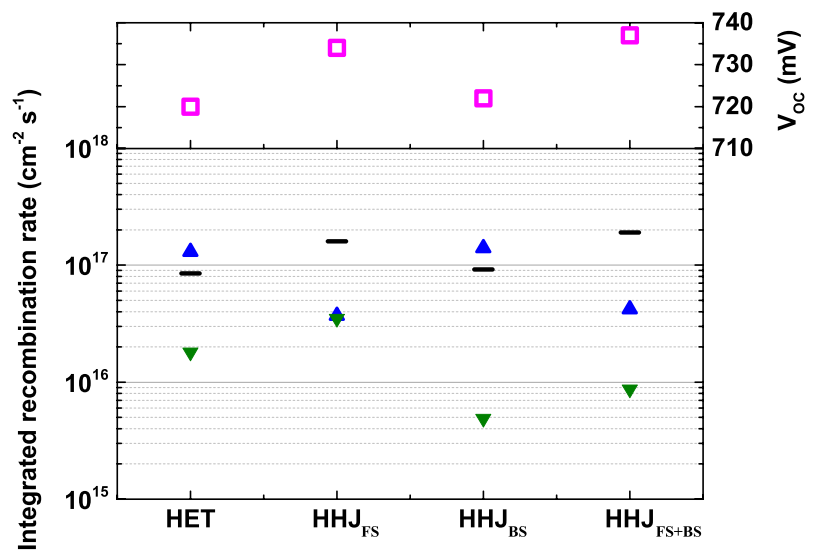

FIG. 8. $\mathrm{V}_{\mathrm{OC}}$ and integrated recombination rates (R) at the front interface, back interface and within the substrate for HET and HHJ architectures. Thicknesses and doping densities are, for both added layers, set at $10 \mathrm{~nm}^{\mathrm{and}} 5 \times 10^{18} \mathrm{~cm}^{-3}$, respectively. 
$\mathrm{HHJ}_{\mathrm{FS}}$ cells, respectively. The increase of recombination rate at the back interface with the addition of the $\left(\mathrm{p}^{+}\right) \mathrm{c}-\mathrm{Si}$ is related to the same mechanism as that inducing the increase in substrate recombination (see Sec. IV A).

From these observations, it can be inferred that there is no great benefit of adding an $\left(\mathrm{n}^{+}\right) \mathrm{c}-\mathrm{Si}$ layer at the back interface of neither the HET nor the $\mathrm{HHJ}_{\mathrm{FS}}$ cell. Therefore, as previously discussed, further passivation improvement should be reached first by substrate improvement rather than back interface improvement.

In Table II, a jsc decrease is observed with the front side layer addition only. This loss originates from light absorption in the added $\left(\mathrm{p}^{+}\right) \mathrm{c}-\mathrm{Si}$ layer which is heavily doped and highly recombining. Therefore, carriers photo-generated in this region cannot fully contribute to the cell current density. Moreover, due to its high doping level, there is also a band gap narrowing $^{26}$ effect (see Figure 2) which promotes the light collection in the layer and thus participates to the current density reduction.

The added $\left(\mathrm{n}^{+}\right) \mathrm{c}-\mathrm{Si}$ layer is located at the cell back side which is reached by less photons than the front side. Therefore, there are much less optical losses due to light absorption in the $\left(\mathrm{n}^{+}\right) \mathrm{c}$-Si layer leading to no jsC loss. This observation opens a new route for a better $\mathrm{HHJ}_{\mathrm{FS}}$ use: an inverted $\mathrm{HHJ}_{\mathrm{FS}}$ cell, with emitter at the cell back side, ${ }^{27}$ would benefit from the passivation improvement without suffering from the $\mathrm{j}_{\mathrm{SC}}$ losses. This idea was validated by our simulations. Because there is no more $\mathrm{j}_{\mathrm{SC}}$ loss, the $\left(\mathrm{p}^{+}\right) \mathrm{c}-\mathrm{Si}$ layer thickness in the inverted $\mathrm{HHJ}_{\mathrm{FS}}$ cell should be optimized again.

\section{CONCLUSION}

An improved silicon heterojunction cell architecture where a $\left(\mathrm{p}^{+}\right) \mathrm{c}-\mathrm{Si}$ layer is added at the front (i)a-Si:H/(n)c-Si interface has been studied by means of numerical simulations. The obtained $\mathrm{HHJ}_{\mathrm{FS}}$ cell displays improved $\mathrm{V}_{\mathrm{OC}}$ and FF. These improvements have been evidenced to originate from an enhanced interfacial field effect passivation. The added $\left(\mathrm{p}^{+}\right) \mathrm{c}-\mathrm{Si}$ layer has been optimized. In order to maximize the hetero-homojunction power conversion efficiency, the $\left(\mathrm{p}^{+}\right) \mathrm{c}$-Si layer doping should be as high as possible to promote field effect passivation at both the interface and in the $\left(\mathrm{p}^{+}\right) \mathrm{c}-\mathrm{Si}$ layer. The corresponding optimum thickness, for the tested doping levels (up to $5 \times 10^{18} \mathrm{~cm}^{-3}$ ), is always very thin $(<40 \mathrm{~nm}$ ). Therefore, we have evidenced the need of ultra-shallow junctions to benefit from such a layer addition. However, under $100 \mathrm{~nm}$ thick, the added layer is thin enough to retain the HHJ cell architecture advantages. Such thin layers should be experimentally achievable at relatively low cost. Finally, adding an $\left(\mathrm{n}^{+}\right) \mathrm{c}-\mathrm{Si}$ layer at the back (n)c-Si/(i)a-Si:H interface was tested. This does not provide a great benefit because passivation of the HET and $\mathrm{HHJ}_{\mathrm{FS}}$ cells are not limited by the back interface. Experiments are ongoing to experimentally achieve hetero-homojunction cells.

\section{ACKNOWLEDGMENTS}

The authors would like to acknowledge the French Environment and Energy Management Agency (ADEME) and the French Alternative Energies and Atomic Energy Commission (CEA) for funding this work. This study was also supported by the European Union through the HERCULES project which has received funding from the European Union's Seventh Programme for research, technological development, and demonstration under Grant Agreement No. 608498.

${ }^{1}$ D. Munoz, A. S. Ozanne, S. Harrison, A. Danel, F. Souche, C. Denis, A. Favier, T. Desrues, S. Martin de Nicolas, N. Nguyen, P. E. Hickel, P. Mur, T. Salvetat, H. Moriceau, Y. Le-Tiec, M. S. Kang, K. M. Kim, R. Janin, C. Pesenti, D. Blin, T. Nolan, I. Kashkoush, and P. J. Ribeyron, in 2010 35th IEEE Photovoltaic Specialists Conference (IEEE, 2010), pp. 000039-000043.

${ }^{2}$ M. Taguchi, A. Yano, S. Tohoda, K. Matsuyama, Y. Nakamura, T. Nishiwaki, K. Fujita, and E. Maruyama, IEEE J. Photovoltaics 4, 96 (2014).

${ }^{3}$ D. Lachenal, Y. Andrault, D. L. Bätzner, C. Guerin, M. Kobas, B. Mendes, B. Strahm, M. Tesfai, G. Wahli, A. Buechel, A. Descoeudres, G. Choong, R. Bartlomé, L. Barraud, F. Zicarelli, P. Bôle, L. Fesquet, and J. Damon-Lacoste, in 25th European Photovoltaic Solar Energy Conference Exhibition/5th World Conference on Photovoltaic Energy Conversion, 6-10 September 2010 (Val. Spain, 2010), pp. 1272-1275. 
${ }^{4}$ J. Kegel, H. Angermann, U. Stürzebecher, E. Conrad, M. Mews, L. Korte, and B. Stegemann, Appl. Surf. Sci. 301, 56 (2014).

${ }^{5}$ P. J. R. D. Muñoz, T. Desrues, A.-S. Ozanne, S. de Vecchi, S. M. de Nicolàs, F. Jay, F. Souche, N. Nguyen, C. Denis, C. Arnal, G. d'Alonzo, J. Coignus, W. Favre, T. Blevin, A. Valla, F. Ozanne, and T. Salvetat, in Proceedings 27th European Photovoltaic Solar Energy Conference and Exhibition, Frankfurt, Germany (2012), pp. 576-579.

${ }^{6}$ Panasonic, Panasonic HIT Solar Cell Achieves World's Highest Energy Conversion Efficiency of 25.6\% at Research Level, Press release, 2014, see http://news.panasonic.com/press/news/official.data/data.dir/2014/04/en140410-4/ en140410-4.html.

${ }^{7}$ M. Schmidt, L. Korte, A. Laades, R. Stangl, C. Schubert, H. Angermann, E. Conrad, and K. V. Maydell, Thin Solid Films 515, 7475 (2007)

${ }^{8}$ M. S. H. Angermann, T. F. Schulze, E. Conrad, J. Rappich, and L. Korte, in Proceedings of 23rd European Photovoltaic Solar Energy Conference, 1-5 September 2008 (Val. Spain, 2008), pp. 1422-1426.

${ }^{9}$ S. Xiao and S. Xu, Crit. Rev. Solid State Mater. Sci. 39, 277 (2014).

${ }^{10}$ M. Mikolášek, P. Príbytný, D. Donoval, J. Marek, A. Chvála, M. Molnár, and J. Kováč, Appl. Surf. Sci. 312, 145 (2014).

${ }^{11}$ S. Zhong, X. Hua, and W. Shen, IEEE Trans. Electron Devices 60, 2104 (2013).

${ }^{12}$ B. Hekmatshoar, D. Shahrjerdi, and D. K. Sadana, in 2011 International Electron Devices Meeting (IEEE, 2011), pp. 36.6.1-36.6.4

${ }^{13}$ Physics and Technology of Amorphous-Crystalline Heterostructure Silicon Solar Cells, edited by W. G. J. H. M. van Sark, L. Korte, and F. Roca (Springer Berlin, Heidelberg, 2012), Chap. 4.

${ }^{14}$ M. Powell and S. Deane, Phys. Rev. B 53, 10121 (1996).

${ }^{15}$ M. Powell and S. Deane, Phys. Rev. B 48, 10815 (1993).

${ }^{16}$ S. C. Deane and M. J. Powell, J. Appl. Phys. 74, 6655 (1993).

${ }^{17}$ R. Varache, J. P. Kleider, M. E. Gueunier-Farret, and L. Korte, Mater. Sci. Eng. B 178, 593 (2013).

${ }^{18}$ J. G. Fossum, R. P. Mertens, D. S. Lee, and J. F. Nijs, Solid-State Electron. 26, 569 (1983).

${ }^{19}$ S. Bellone, G. Busatto, and C. M. Ransom, IEEE Trans. Electron Devices 38, 532 (1991).

${ }^{20}$ J. P. Kleider, Y. M. Soro, R. Chouffot, A. S. Gudovskikh, P. Roca i Cabarrocas, J. Damon-Lacoste, D. Eon, and P.-J. Ribeyron, J. Non-Cryst. Solids 354, 2641 (2008).

${ }^{21}$ R. Varache, W. Favre, L. Korte, and J. P. Kleider, J. Non-Cryst. Solids 358, 2236 (2012).

${ }^{22}$ M. Filipič, Z. C. Holman, F. Smole, S. De Wolf, C. Ballif, and M. Topič, J. Appl. Phys. 114, 74504 (2013).

${ }^{23}$ H. S. Emmer, M. G. Deceglie, Z. C. Holman, A. Descoeudres, S. De Wolf, C. Ballif, and H. A. Atwater, in 2013 IEEE 39th Photovoltaics Specialists Conference (IEEE, 2013), pp. 1229-1231.

${ }^{24}$ F. Torregrosa, C. Laviron, F. Milesi, M. Hernandez, H. Faik, and J. Venturini, Nucl. Instrum. Methods Phys. Res., Sect. B 237, 18 (2005).

${ }^{25}$ F. Torregrosa, C. Laviron, H. Faik, D. Barakel, F. Milesi, and S. Beccaccia, Surf. Coat. Technol. 186, 93 (2004).

${ }^{26}$ D. Yan and A. Cuevas, J. Appl. Phys. 114, 044508 (2013).

${ }^{27}$ T. Desrues, P.-J. Ribeyron, A. Vandeneynde, A.-S. Ozanne, F. Souche, D. Muñoz, C. Denis, D. Diouf, and J.-P. Kleider, Phys. Status Solidi 7, 1011 (2010). 